\title{
Rethinking Gender in Revolutions and Resistance: Lessons from the Arab world
}

DOI:

10.1080/13552074.2016.1154256

\section{Document Version}

Final published version

Link to publication record in Manchester Research Explorer

\section{Citation for published version (APA):}

Smail Salhi, Z. (2016). Rethinking Gender in Revolutions and Resistance: Lessons from the Arab world. Gender and Development, 24(1), 152-154. https://doi.org/10.1080/13552074.2016.1154256

\section{Published in:}

Gender and Development

\section{Citing this paper}

Please note that where the full-text provided on Manchester Research Explorer is the Author Accepted Manuscript or Proof version this may differ from the final Published version. If citing, it is advised that you check and use the publisher's definitive version.

\section{General rights}

Copyright and moral rights for the publications made accessible in the Research Explorer are retained by the authors and/or other copyright owners and it is a condition of accessing publications that users recognise and abide by the legal requirements associated with these rights.

\section{Takedown policy}

If you believe that this document breaches copyright please refer to the University of Manchester's Takedown Procedures [http://man.ac.uk/04Y6Bo] or contact uml.scholarlycommunications@manchester.ac.uk providing relevant details, so we can investigate your claim.

\section{OPEN ACCESS}




\section{Gender \& Development}

\section{Rethinking Gender in Revolutions and Resistance: Lessons from the Arab world}

\section{Zahia Smail Salhi}

To cite this article: Zahia Smail Salhi (2016) Rethinking Gender in Revolutions and Resistance: Lessons from the Arab world, Gender \& Development, 24:1, 152-154, DOI: 10.1080/13552074.2016.1154256

To link to this article: http://dx.doi.org/10.1080/13552074.2016.1154256

曲 Published online: 03 Mar 2016.

Submit your article to this journal $₫$

Џ Article views: 29

Q View related articles $๘$

View Crossmark data $₫$ 
which, over time, reinforce inequality at least as much as catastrophic disasters, could have been developed in relation to Rob Nixon's concept of 'slow violence' that Joane Nagel uses (p. 103) to explain how such experiences in poor countries, while not well enough documented to prove causation due to climate change, undoubtedly have an impact on people's lives.

Joane Nagel draws quite a few parallels between the gendering of climate change and the gendering of health, medicine, and the pharma industry, on the basis that evidence of gender disparities are much better documented in the medical and pharmaceutical sciences. At times, a focus on this seems a little distracting and not sufficiently focused on climate change, although it could be pointed out that the work being done in these areas would be a good model for climate change science to emulate. However, these are minor criticisms of a book which deserves a wide reading amongst students of climate change, and environmental science more generally. The book reveals how fundamental an understanding of gender is to appreciating how climate change is produced, experienced and addressed. With the world at such a pivotal moment in determining how it should respond to climate change in order to avert catastrophe, Joane Nagel has provided a departure point for those engaged in studying and making decisions on climate change, as well as those challenging these decisions, to consider the central role of gender in this 'greatest threat to rights in our time' (6).

\title{
Notes
}

(1) Women and Gender Constituency (2015) http://womengenderclimate.org/a-reality-checkon-the-paris-agreement-women-demand-climate-justice/ (last checked by the author 24 December 2015).

(2) Masika, Rachel (ed.) (2002) Gender, Development and Climate Change: Oxfam Focus on Gender Series, Oxford: Oxfam.

(3) Eckhardt, William (1989) 'Civilian Deaths in Wartime' Security Dialogue 20 (1): 89-98.

(4) Madelyn Hsiao-Rei Hicks, M.R, Hamit Dardagan, Gabriela Guerrero Serdán, Peter M. Bagnall, John A. Sloboda, and Michael Spagat (2009) 'The Weapons That Kill Civilians - Deaths of Children and Noncombatants in Iraq, 2003-2008', New England Journal of Medicine 360:1585-1588

(5) Alston, Margaret (2015) 'Gendered outcomes in post-disaster sites: public policy and resource distribution', Paper presented at the Workshop on Gender, Labour and Climate Change, Simon Fraser University, Vancouver, Canada, 24-26 June.

(6) See note 1.

\author{
Susan Buckingham \\ Independent Researcher, Writer and Activist, UK \\ Q susanbuckingham07@gmail.com \\ (C) 2016 Susan Buckingham \\ http://dx.doi.org/10.1080/13552074.2016.1154243
}

Rethinking Gender in Revolutions and Resistance: Lessons from the Arab world, edited by El Said, Maha, Meari, Lena, and Pratt, Nicola, London: Zed Books, 2015, 262 pp., ISBN: 9781783602827

Across the globe, women's role in revolutions and national uprisings has always been problematic. While their participation and integration into nationalist movements is usually welcomed up to a point, the recognition of women's roles as revolutionaries tends to be a bone of contention amongst various parties in post-revolution periods. In Partha Chaterjee's words, 'The story of nationalism is necessarily a story of betrayal' (Chaterjee 1993, p. 154). A classic example, which directly relates to 
the Arab world, is the Algerian revolution (1954-1962) in which women played active roles and challenged the forces of patriarchy,

In the twenty-first century, and following the so-called 'Arab Spring uprisings' we are again compelled to consider women's roles in resistance and revolution, to which end the editors and authors of this book have made a timely and valuable contribution.

From the outset, the contents of the volume challenge a plethora of assumptions, starting with the dichotomy between the post-Arab spring discourses which either celebrate women's participation, or highlight the looming threat of conservative forces to women's rights. Furthermore, the authors question the term 'Arab Spring', which was disputed across the Middle East and North Africa (MENA) from its inception.

The book opens with an introductory chapter by the editors, then is organised into three sections: Part One - Reconstructing Gender in Post-revolutionary Egypt; Part Two - The Body and Resistance; and Part Three - Gender and the Construction of the Secular/Islamist Binary, with the editors providing a final, concluding chapter.

Five of the eight chapters from contributors focus on Egypt, with the other three dedicated to Palestine, Libya and Tunisia, respectively.

The chapters on Egypt, though spread across Part I and Part II complement each other, representing a full picture of women's participation in the Egyptian 'revolution' since 2011.

In her chapter 'Reconstructing Gender in Post-Revolution Egypt', Shireen Abouelnaga describes Egyptian women's participation as citizens, not as women, in the eighteen day events leading to the overthrow of Hosni Mubarak. She argues that gender became a priority only when 'the Utopia of the Eighteen Days turned into a dystopia' (p. 36), with the violence experienced by women during these events constituting a strong wakeup call to Egyptian feminists, who deplored the exploitation of women's bodies as political battlefields.

Hala G. Sami's chapter explores the use of popular culture, namely; the political-activist movement known as Baheya Ya Masr, the caricatures of the satirical cartoonist Doaa Eladl, and the graffiti movement known as Women on Wall in challenging the relegation of women to the periphery of civil society, post revolution.

Chapters by Maha El Said, and Abeer Al-Najjar and Anoud Abusalim, focus on body politics, with both contributions examining the mounting of a form of 'body resistance' by women to the patriarchal attitudes of both Islamist and secular political actors. Maha El Said discusses Aliaa Magda, the nude blogger and Sama El-Masry, the belly dancer, who used their bodies for political action and to subvert the image of woman as a passive body. Abeer Al-Najjar and Anoud Abusalim also DISCUSS Aliaa along with Tunisian FEMEN activist, Amina Sboui and investigates the degree to which the Arab spring inspired women to use their bodies as means to express political dissidence and the public outrage that followed their nude poses on social media. These activists failed to find support, given the overriding belief within Arab/Muslim patriarchal societies that a woman's body is the property of her people and the site of their 'honour'.

Lena Meari explores the acts of resistance of Palestinian women political prisoners in Israeli prisons. Drawing on the Algerian paradigm both on the practice of torture on women prisoners in colonial prisons, and on the theoretical works of Fanon and Lazreg,. In both cases, torture is used as part and parcel of a subjugation designed to combat revolutionary struggle, with Palestinians transforming arrest and the body into sites of resistance.

However, instead of the body as a site of resistance in the countries that experienced the 'Arab Spring' women's bodies are positioned as political battlefields, with serious implications for women's roles and visibility in the public sphere, something which in itself is highly counter revolutionary.

This is demonstrated in all the chapters discussed above, as well as in the chapter by Sahar Mediha Elnaas and Nicola Pratt on women's bodies in post-revolution Libya, where they endeavour to demonstrate that despite being victims of the political transition Libyan women have gained agency by resisting their marginalisation in the public sphere through their bodily performances which 
include Friday bicycle rides across Tripoli, the donning of the Farashiya (traditional Libyan veil) as a substitute to the black Islamic veil imposed by the Salafists, and through political advocacy exemplified in the single case of Amal Bilhaj, the first woman candidate to stand for the position of prime minister in Libya.

Despite the case being made for women's agency in the aforementioned examples, in all three cases women were acting within the confines of religious conservatism, making sure not to break any boundaries, thus confirming the 'anti-revolutionary', aspect of the Libyan 'spring', which heralded an era of loss of acquired rights and further control of women in both the public and private spheres.

The last chapter in this volume is on what Aitemad Muhanna terms 'Post-Uprising' Tunisia. The author examines the discourses of both secular and Islamic women, arguing that the Islamic-secular binary is an artificial construct which does not reflect the actual gender politics adopted by the two groups who militate for a common cause.

Overall, this volume presents a wealth of views and interpretations of the 'Arab Spring uprisings' and its impact on women. In fact, the chapters in this volume do not agree over whether to call them revolutions or not, and where the term is used it is in contexts where such 'revolutions', if anything, propelled the resurfacing of counter-revolutionary and conservative forces, in which attempts to control women's bodies and place in the public sphere has been apparent right from the start. Although the editors of the book argue that a return to local culture is not necessarily against women's emancipation, I would argue that if a revolution fails to challenge the status quo and to shake traditional perceptions of gender roles at all levels, then it does not deserve to be called a revolution. That this is the case is demonstrated by the lack of consensus among the contributors to this volume over the naming of these events, and whether to call them 'springs', 'uprisings' or 'revolutions'.

\section{Reference}

Chaterjee, Partha (1993) Nationalist Thought and the Colonial World: A Derivative Discourse, Minneapolis: University of Minnesota Press.

Zahia Smail Salhi School of Arts, Languages and Cultures, University of Manchester, UK Q zahia.smailsalhi@manchester.ac.uk

(C) 2016 Zahia Smail Salhi http://dx.doi.org/10.1080/13552074.2016.1154256

\section{Beyond Mothers, Monsters, Whores: Thinking About Women's Violence in Global Politics, by Gentry, Caron E., and Sjoberg, Laura, London: Zed Books, 2015, pp. 208, ISBN: 978-1- 78360-207-0}

This is a second and significantly revised version of the original title by Caron Gentry and Laura Sjoberg, published in 2007. A central plank of their argument is that women's involvement in political violence is systematically denied, denigrated, or assumed to be driven by personal, and thus apolitical forces - and hence is explained away by 'maternalism, mental instability or deviant sexuality' (p. 41). Second, and related to this, is that women's political violence is always understood as different to men's: in this view, 'men who commit violence make autonomous decisions, while women who do so are controlled, coerced or insane' (p. 44) - although in reality, of course, 'all decisions are contextual and contingent, not only women's, and all decisions are made, not only men's' (p. 46). Third, while contrasting representations and readings of male and female violence 